\title{
Douglas in retrospect
}

\author{
DERMOD MACCARTHY
}

For those readers of the Archives who have never met Douglas Gairdner he is a tall, good looking man with a very straight back for his age, who carries his head on his shoulders in a youthful manner. He has a slightly Grecian nose and a forehead that is transversely heavily lined, due to moods of levity rather than gravity, as with the creases round his eyes. His hair which was blond has not turned grey or white in his sixties but brown, and being as thick as ever gives a remarkable impression of youth. But, let me say at once, it is not just an impression for he still is in every way extraordinarily young.

It is difficult to describe a man who, because of his capacity to respond to people of all kinds and his liking for intimacy, may present a different image to each of his many friends. Therefore some personal reminiscences must suffice to give an impression of him in the hope that some people will recognise in them resemblances to their own pictures of Douglas.

A few years ago Douglas, when introducing me to someone, added after my name, "who is my oldest friend'. That warmed me. I could not have wished for an adjective, as a friend, that I liked better. We were both at Gresham's School, Holt and met there about 54 years ago. I remember him then as a good deal smaller than me, although slightly older. When I met him in later years he had shot up. He told me that a late puberty was the reason for this and he always held that it had been an advantage to have been held back by it from his proper age group and then to put on a sprint to manhood at a mentally maturer age. It was much to be recommended, he said. When we met again at Great Ormond Street in 1939 (he a stepping stone or two ahead on the path to paediatrics) we at once started to compare experiences at that puritan but civilised school. I told him that in class we relied on him to bring the master down as David did Goliath. This he did by being sometimes urchin, sometimes puck, imp, buffoon, or leprechaun, 'getting the wires crossed', and of course translating the Latin prose into absurdities which he then defended with many a pained ... 'but Sir!'. It was very good to find him again and a friendship developed that at school had only been slight. We shared a house in Chelsea until war was declared in September, a delightful 9 months of cooking experiments, music, intimate talk, and flirting with the 'daily'.
At the start of war we were both posted as 'Blood Transfusion Officers' (in anticipation of massive air raid casualties) to the Royal National Orthopaedic Hospital at Stanmore, where an insoluble residue of children from Great Ormond Street had been bundled down to be in comparative safety and where we were to continue to look after them in our spare time. The house in Chelsea was to be left to its fate. It was good bye to all that. We had hurriedly to pack Douglas's car with all our essential belongings and be off. What was 'essential'? That was a good question. There was an exhilaration in discovering that in fact nothing was. I left a great heap of things on the floor unpacked as mere paraphernalia. When we slammed the door and drove off it was a golden afternoon, with a sky that was soon to be blackened by hundreds of bombers. I noticed that Douglas was smiling. Turning round in my seat I noticed his golf clubs rather vulgarly sticking out of the back window. He liked mock heroics.

'Mock obituaries' was a game Douglas invented. We were young and flippant and made fun of the cliché-ridden obituaries of the $B M J$ of the time, doing our own or each other's as we drove from Chelsea to Great Ormond Street in the morning, or employing extravagant 'obituareese' to clap wings on the backs of our dullest contemporaries or most pompous seniors. There was also the 'back to nature obstetrics' game in which Douglas had designed a mock hospital consisting of caves in which women would be delivered in straw, naked of course, and in order to have and to hold the baby immediately would bite through the cord with their teeth; but just to be on the safe side, would undergo a short course of dental hygiene in the antenatal period. Prophetic perhaps?

In our London days we often discussed music and played flute duets, which to be honest were not a great success. Sometimes we played our gramophone records, particularly Nadia Boulanger's marvellous production of Monteverdi's madrigals, something quite new to us and to many young music lovers at the end of the 'thirties. Once, when talking about Handel's Messiah, Douglas made a remark which I was to remember long afterwards; he said how impressed he was by the power of the words in one of the arias ... 'A man of sorrow, and acquainted with grief'. Warmth and generosity of response to 
people whether or not in trouble or in need of sympathy we think of as kindness; but an intenser degree of this we would call love. I remembered that remark of Douglas's when, years later, he and Nancy were indeed acquainted with grief, for he became, not a man of sorrow, but one whose kindness was intensified in this way.

Can one distinguish one paediatrician's feelings towards children, as patients, from another's? Yes, of course; but it may be difficult to express it. Douglas always had, quite unsentimentally, a particularly tender feeling for very young children, a feminine as well as a fatherly concern for them, so spontaneous, so beautiful, so vulnerable. He hated seeing them in hospital and in 1956 he gave a paper to the Royal Society of Medicine entitled 'The decline and fall of hospital paediatrics'. Throughout his 27 years at Cambridge he worked with very few beds and could be acclaimed as the paediatrician who admitted the fewest children to hospital and kept them there for the shortest time. It was not his fault that some people, particularly administrators, in the early years of the NHS interpreted the title, and not the substance of his paper, to mean that paediatrics was a dying speciality and that paediatricians, like the tuberculosis officers, were sawing off the branch they were sitting on. We knew what he meant by 'hospital paediatrics'- the child who, no matter how young. languished from week to week in a hospital ward (which was also a sort of museum), between visits of the big chief.

How can one describe him as a man to work with or do things with? The simile that seems most apt for his relationship with others in work or various pursuits is that of first violin in a quartet. Not the grand soloist or the leader of the orchestra but a gifted dominant player, who at the same time feels and needs the music of the other players. In the pages that follow something of this will be appreciated, but for an example of a pursuit, why not take sailing? It is a great test of friendship, loyalty, and niceness or leanings to selfishness. Douglas in a boat is certainly the first fiddle, but how the quartet plays! My first experience of playing under his bow was in 1939 , when he knew rather little about it, if I may say so now when he is a great small-boat mariner. The 'Merrythought' was a small shallow-draught yacht. We were 4 aboard. As we sailed out of a little Essex creek towards the sea she suddenly slowed down, then stopped. Instantly we were ordered overboard to shove her off the mud. Stripped to the waist, that is from below upwards, and with shirt tails floating on the turbid water, we pushed and heaved until away we went, clambering aboard with long black stockings, or tights in one case, which we were ordered to wash off before being allowed in the cockpit. But 40 years later, what expert knowledge of navigation and seamanship he has. Sailing back with him from Galway to Harwich I appreciated the enormous amount of planning and detailed care which must have meant plenty of apposite suggestions from Nancy. Much experience and responsibility were displayed in that voyage out and back, in his $31 \mathrm{ft}$ 'Lal', so named after a woman who for him from childhood onwards, had always epitomised everything female and femininely beautiful, even in her nineties. The quartet played allegretto or allegro con brio all the way and never was there any of the dreadful heartiness and banter that can take possession of the crew of a yacht at sea. Douglas has twice circumnavigated Scotland and has described it beautifully in the $B M J$. Now he is returned from crossing the Bay of Biscay this year we shall expect another beautiful clear seascape in words.

It is sad that many readers of the Archives or Recent Advances in Paediatrics, who do not know and may never know Douglas Gairdner, must make do with such a sketch as this. And must be resigned not to hear one of his brilliant imitations, which his friends are often treated to, in the form of lightning impromptu charades, all over in a moment, leaving his audience and himself in fits of laughter. 